\title{
Rhizoctonia solani a threat in carnation (Dianthus caryophyllus) production
}

\author{
Zagrożenie goździków (Dianthus caryophyllus) przez Rhizoctonia solani
}

\author{
Leszek B. Orlikowski, Magdalena Ptaszek, Wojciech Warabieda
}

\section{Summary}

In five monitored farms, stem base rot symptoms and carnation wilting were observed on $10-35 \%$ of plants and Rhizoctonia solani was the most frequently isolated species from diseased tissues. Additionally Fusarium avenaceum and Botrytis cinerea were only rarely noticed in the diseased stem parts. Isolates from carnation and eustoma caused stem and leaf blade rot of carnation but tissues were colonized significantly faster by a culture from a host plant. Different reaction of three carnation cultivars was observed on $R$. solani inoculation. The optimal species growth was observed at $30^{\circ} \mathrm{C}$ and it was also the most favorable temperature for colonization of carnation stem parts. In the greenhouse trial isolate of $R$. solani obtained from carnation crops caused stem base rot already after 2-week-growth on 1 per 5 plant in each replication and within the next 2 weeks 4 per 5 of plants died.

Key words: carnation; Rhizoctonia solani; isolates; colonization; temperature

\section{Streszczenie}

W pięciu lustrowanych gospodarstwach stwierdzono występowanie zgnilizny podstawy pędów i więdnięcie goździków, a z porażonych tkanek izolowano głównie Rhizoctonia solani. Obok tego gatunku rzadko lub sporadycznie stwierdzono w tkankach Fusarium avenaceum i Botrytis cinerea. Izolaty $R$. solani z goździka i eustomy powodowały zgniliznę części łodyg i liści, przy czym tkanki kolonizowane były szybciej przez kulturę z rośliny żywicielskiej. Stwierdzono również istotne różnice w kolonizacji organów 3 odmian goździka. Wykazano, iż optymalną temperaturą dla rozwoju grzyba było $30^{\circ} \mathrm{C}$ i również w tej temperaturze najszybciej przebiegała kolonizacja części łodyg goździka. W doświadczeniu szklarniowym, uprawa goździków w podłożu zakażonym przez izolat $R$. solani z tej rośliny powodowała wystąpienie zgnilizny postawy pędu po 2-tygodniowej uprawie na co najmniej 1 z 5 roślin w powtórzeniu i 4/5 roślin w ciągu następnych 2 tygodni.

Słowa kluczowe: goździk; Rhizoctonia solani; izolaty; kolonizacja; temperatura 


\section{Wstęp / Introduction}

Do lat 90. XX wieku goździki (Dianthus caryophyllus L.), obok róż, były głównymi roślinami uprawianymi na kwiat cięty. Wprowadzenie do produkcji storczyków, anturium i eustomy spowodowało zminimalizowanie uprawy goździków. Obecnie powierzchnia ich uprawy wzrasta ze względu na mniejsze potrzeby energetyczne tych roślin. Do najgroźniejszych chorób goździków należy niewątpliwie fuzarioza naczyniowa powodowana przez Fusarium oxysporum f. sp. dianthi (Orlikowski i Dzięcioł 1976/77). Od 3 lat stwierdza się wzrost zagrożenia nasadzeń roślin ozdobnych przez Rhizoctonia solani (Orlikowski i Ptaszek 2013), w tym również goździków. O chorobie tej wspomina już Mynett (1984) oraz Werner (1997) jako przyczynie zgnilizny podstawy pędów. O szkodliwości rizoktoniozy i możliwości jej biologicznego oraz chemicznego zwalczania donoszą Elad i wsp. (1981) oraz Sharma i Chandel (2013). Mimo rosnącego zagrożenia goździków i potrzeby opracowania epidemiologii tego patogena na tych roślinach w minionym 20-leciu nie podjęto $\mathrm{w}$ Polsce tego zagadnienia.

Celem badań była ocena występowania $R$. solani w nasadzeniach goździków w Polsce oraz określenie chorobotwórczości tego gatunku dla goździków szklarniowych.

\section{Materiały i metody / Materials and methods}

\section{Ocena zagrożenia goździków przez $R$. solani oraz analiza mikologiczna porażonych roślin}

W latach 2011-2013 przeprowadzono ocenę strat spowodowanych wystapieniem zgnilizny podstawy pędów goździków uprawianych w substracie torfowym w 5 gospodarstwach, w tym trzech szklarniach usytuowanych w województwie łódzkim o powierzchni od około 800 do $2000 \mathrm{~m}^{2}$ oraz dwóch $\mathrm{w}$ tunelach foliowych w okolicy Częstochowy o średniej powierzchni około $1000 \mathrm{~m}^{2}$. Sadzonki produkowane $\mathrm{w}$ wielodoniczkach lub pobierane z parapetów do ukorzeniania sadzono w kwietniu-maju na zagonach $\left(40\right.$ szt. na $\left.\mathrm{m}^{2}\right)$. Choroba pojawiła się w 2 gospodarstwach pod koniec maja, a w pozostałych w czerwcu i lipcu. Pierwsze objawy wystapiły na pojedynczych pędach, których liście u nasady żółkły i brązowiały. Pędy były znekrotyzowane na całym obwodzie na długości od około 1 do $3 \mathrm{~cm}$. Z tego powodu całe pędy więdły i liście zmieniały zabarwienie na jasnobrązowe. Następnie choroba rozszerzała się stopniowo na pozostałe pędy. Rośliny z objawami infekcji występowały gniazdowo po kilka-kilkanaście roślin, a wraz z upływem czasu choroba rozszerzała się na zagonie. Straty z powodu wypadania roślin $\mathrm{w}$ gospodarstwach szklarniowych wahały się od około 20 do $35 \%$, a w tunelach odpowiednio 10 i $20 \%$. W celu stwierdzenia przyczyny choroby z zagonów, z 4-5 miejsc $\mathrm{w}$ każdym $\mathrm{z}$ obiektów pobierano reprezentacyjne dla występujących objawów chorobowych chore rośliny. Ogółem ze wszystkich gospodarstw pobrano 60 porażonych roślin, które po wyrwaniu wkładano indywidualnie do worków foliowych i przewożono do laboratorium. Po otrzaśnięciu roślin z podłoża myto je pod bieżącą wodą, wybierano po $2-3$ pędy $\mathrm{z}$ objawami zgnilizny podstawy i osuszano je pomiędzy warstwami bibuły filtracyjnej. Następnie z pędów wycinano około 5-centymetrowe fragmenty i odkażano je nad płomieniem palnika (Orlikowski i Szkuta 2002). Z każdego z nich wycinano skalpelem około $5 \mathrm{~mm}$ długości fragmenty tkanki i przenoszono je na płytki Petriego o średnicy $90 \mathrm{~mm} \mathrm{z}$ pożywką ziemniaczano-glukozową (Merck). W ciagu 48-72 godzin inkubacji w temperaturze $25^{\circ} \mathrm{C}$ płytki przeglądano i przeszczepiano z nich fragmenty rosnącej grzybni. Uzyskane kultury grzybów oznaczano do rodzajów i gatunków na podstawie dostępnych kluczy i monografii. Do badań włączono również izolat $R$. solani uzyskany $\mathrm{z}$ eustomy z objawami zgnilizny podstawy pędu stosując taką samą metodę, jak przy analizie mikologicznej goździków.

\section{Ocena chorobotwórczości izolatów $R$. solani dla goździków}

Do testów wybrano losowo po jednym izolacie $R$. solani uzyskanym z porażonej podstawy pędu goździka (G1) oraz eustomy (Lisanthus grandiflorum) (E5), uprawianej często $\mathrm{w}$ szklarniach i tunelach foliowych przemiennie $\mathrm{z}$ goździkami. W badaniach laboratoryjnych około $50 \mathrm{~mm}$ długości części łodyg i blaszki liściowe odmian: Golem, Genio i Oliva wykładano do kuwet wyłożonych 2 warstwami sterylnej bibuły filtracyjnej przykrytej cienką siatką nylonową $\mathrm{i}$ na ich podstawy nanoszono $3 \mathrm{~mm}$ średnicy krążki pożywki przerośnięte grzybnią, pobrane z brzegów 3-dniowych kultur. Kuwety okrywano szczelnie cienką folią i ustawiano na stołach laboratoryjnych. Po 3 i 6 dniach inkubacji w temperaturze $22-24^{\circ} \mathrm{C}$ mierzono długość nekrozy. Doświadczenia założono w układzie całkowicie losowym w 4 powtórzeniach po 5 organów roślinnych i powtórzono 2-krotnie w odstępie 2-tygodniowym.

\section{Wplyw temperatury na rozwój $R$. solani oraz zgnilizny podstawy lodyg goździka}

W badaniach użyto izolat $R$. solani G1 oraz metodę opisaną przez Hall (1993). Kultury wyjściowe grzyba rosły na pożywce PDA (Potato Dextrose Agar) w temperaturze $25^{\circ} \mathrm{C}$ przez 4 dni, po czym z brzegu kolonii pobierano $5 \mathrm{~mm}$ średnicy krążki grzybni i przenoszono na środek płytek Petriego o średnicy $90 \mathrm{~mm} \mathrm{z}$ pożywką PDA. Na spodniej stronie szalek wykreślano 2 prostopadłe linie, krzyżujące się pod kątem prostym w centrum inokulum. Płytki inkubowano przez 24 godziny w temperaturze $20^{\circ} \mathrm{C}$, w celu zainicjowania wzrostu. Wzrost ten traktowano jako okres preinkubacji i nie brano go pod uwage przy obliczaniu tempa wzrostu. Następnie płytki umieszczono w termostatach, w temperaturach od 10 do $30^{\circ} \mathrm{C}$, w odstępach co $5^{\circ} \mathrm{C}$. Po 2 dniach mierzono średnicę kolonii. W każdej z kombinacji użyto 4 płytek i doświadczenie powtórzono 2-krotnie w odstępie 2 tygodni.

W takim samym zakresie temperatury badano chorobotwórczość $R$. solani w stosunku do tkanek łodyg goździka stosując metodę opisaną przy badaniach chorobotwórczości $R$. solani. Długość nekrozy określano po 3 i 5 dniach inkubacji. 


\section{Rozwój rizoktoniozy goździka w warunkach szklarniowych}

Badania przeprowadzono na ukorzenianych sadzonkach goździków odmiany Genio. Substrat torfowy zakażono izolatami $R$. solani z goźdzka (G1) i eustomy (E5), rosnącymi na płatkach owsianych (Orlikowski 1999). Po wymieszaniu zhomogenizowanych kultur $\mathrm{z}$ podłożem i 10-dniowej inkubacji w szklarni w temperaturze 20-24 ${ }^{\circ} \mathrm{C}$, napełniano nim doniczki o pojemności 0,61 i sadzonkowano do nich ukorzenione sadzonki. Doniczki ustawiano na parapecie w szklarni. W ciągu 4-tygodniowej uprawy w temperaturze $18-26^{\circ} \mathrm{C}$ i wilgotności względnej powietrza $62-78 \%$ notowano liczbę roślin $\mathrm{z}$ objawami zgnilizny podstawy pędu.

Doświadczenia założono w układzie całkowicie losowym w 4 powtórzeniach po 5 roślin i powtórzono 2-krotnie w odstępie 2-tygodniowym.

\section{Wyniki i dyskusja / Results and discussion}

Analiza mikologiczna 60 goździków, pobranych z 5 gospodarstw, wykazała występowanie na porażonej podstawie pędów i liściach głównie $R$. solani. Grzyb ten stwierdzono na 36 z 60 analizowanych roślin w 3 gospodarstwach i na całym materiale roślinnym pobranym z 2 pozostałych gospodarstw (tab. 1). Obok tego gatunku stwierdzano Fusarium avenaceum, znanego patogena goździków oraz Botrytis cinerea, który prawdopodobnie kolonizował tkanki niektórych roślin już po wystąpieniu pierwszych symptomów zgnilizny podstawy pędu. Poza tym izolowano również gatunki rodzajów Mucor, Penicillium i Trichoderma (tab. 1).

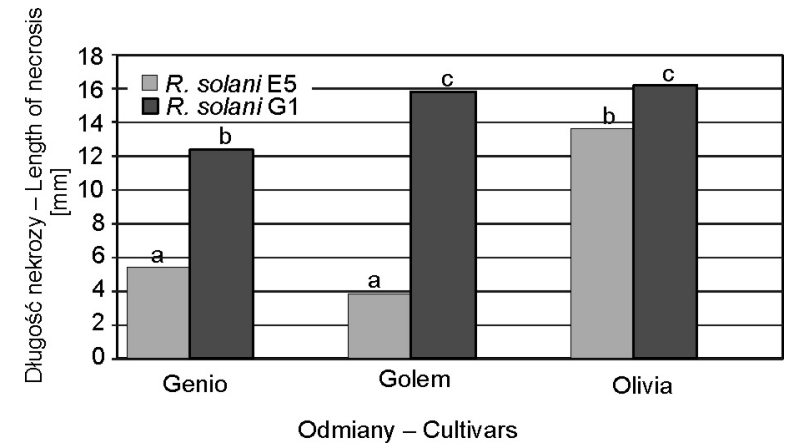

Średnie w słupkach, oznaczone tą samą literą, nie różnią się istotnie (5\%) według testu Duncana

Means in columns, followed by the same letter, do not differ $(5 \%)$ according to Duncan's multiple range test

Rys. 1. Kolonizacja części łodyg 3 odmian goździków przez izolaty $R$. solani po 6 dniach od inokulacji

Fig. 1. Colonisation of stem parts of three carnation cultivars by $R$. solani 6 days after inoculation

Tabela 1. Grzyby wyizolowane z goździków wykazujących objawy zgnilizny podstawy pędu; liczba roślin, z których izolowano grzyby z 5 gospodarstw

Table 1. Fungi isolated from plants with stem base rot symptoms; number of plants from which the fungi were isolated collected from five farms

\begin{tabular}{|c|c|c|c|c|c|}
\hline \multirow[b]{2}{*}{$\begin{array}{l}\text { Rodzaj/gatunek grzyba } \\
\text { Genera/species of fungi }\end{array}$} & \multicolumn{5}{|c|}{ Gospodarstwa - Farms } \\
\hline & $\begin{array}{c}\text { I } \\
15 \text { roślin* } \\
15 \text { plants }\end{array}$ & $\begin{array}{c}\text { II } \\
8 \text { roślin } \\
8 \text { plants }\end{array}$ & $\begin{array}{c}\text { III } \\
12 \text { roślin } \\
12 \text { plants }\end{array}$ & $\begin{array}{c}\text { IV } \\
18 \text { roślin } \\
18 \text { plants }\end{array}$ & $\begin{array}{l}\mathrm{V} \\
7 \text { roślin } \\
7 \text { plants }\end{array}$ \\
\hline Botrytis cinerea Pers. & 2 & 1 & - & 4 & 2 \\
\hline Fusarium avenaceum (Fr.) Sacc. & - & 1 & 2 & 1 & 3 \\
\hline Mucor spp. & 2 & 3 & 3 & - & 1 \\
\hline Penicillium spp. & 4 & 5 & 6 & 2 & 1 \\
\hline Rhizoctonia solani Kühn & 14 & 6 & 12 & 16 & 7 \\
\hline Trichoderma spp. & 3 & 2 & 5 & 2 & 2 \\
\hline
\end{tabular}

*matecznik goździków - mother plants

Tabela 2. Współzależność pomiędzy odmianą goździka, źródłem $R$. solani a kolonizacją liści goździka; długość nekrozy po 6 dniach inkubacji [mm]

Table 2. Relationship between carnation cultivar, source of $R$. solani and colonisation of carnation leaf blades, length of necrosis 6 days after inoculation [mm]

\begin{tabular}{l|c|c}
\hline \multirow{2}{*}{$\begin{array}{c}\text { Odmiany } \\
\text { Cultivars }\end{array}$} & \multicolumn{2}{|c}{ Izolaty $R$. solani- Isolates of $R$. solani } \\
\cline { 2 - 3 } Golem & eustoma - lisianthus (E5) & goździk - carnation (G1) \\
\hline Genio & $3,8 \mathrm{a}$ & $14,8 \mathrm{~d}$ \\
\hline Oliva & $5,9 \mathrm{~b}$ & $11,8 \mathrm{c}$ \\
\hline
\end{tabular}

Średnie w kolumnach, oznaczone tą samą literą, nie różnią się istotnie (5\%) według testu Duncana

Means in columns, followed by the same letter, do not differ (5\%) according to Duncan's multiple range test 
W doświadczeniu laboratoryjnym oba izolaty $R$. solani kolonizowały liście i części łodyg trzech odmian goździka (tab. 2, rys. 1). W przypadku inokulacji podstawy łodyg izolatem G1 z goździka, po 6 dniach inkubacji nekroza widoczna była na długości od około 13 do $16,5 \mathrm{~mm}$. Zgnilizna rozwijała się nieznacznie wolniej na łodygach odmiany Genio (rys. 1). Stwierdzono istotnie wolniejsza kolonizację łodyg przez izolat E5 z eustomy w porównaniu z kulturą $R$. solani z goździka (rys. 1). Podobne współzależności w kolonizacji tkanek trzech odmian goździka stwierdzono na blaszkach liściowych (tab. 2). Po 6 dniach inkubacji liście kolonizowane były około 2-3-krotnie wolniej przez kulturę E5 z eustomy, a długość nekrozy wynosiła od 3,8 do 5,9 mm, podczas gdy w kombinacji z izolatem G1 z goździka od 11,8 do 14,8 mm (tab. 2).

W badaniach nad wpływem temperatury na rozwój izolatu G1 $R$. solani stwierdzono, iż grzyb ten rozwija się w zakresie temperatury od $10^{\circ} \mathrm{C}(1,4 \mathrm{~mm} / 24 \mathrm{~h})$ do $30^{\circ} \mathrm{C}$ $(16,2 \mathrm{~mm} / 24 \mathrm{~h})$ przy optimum $30^{\circ} \mathrm{C}$ (rys. 2). Kolonizację części łodyg zainokulowanych badanym izolatem obserwowano w tym samym zakresie temperatury, a nekroza rozwijała się najszybciej w temperaturze $30^{\circ} \mathrm{C}$ i po 5 dniach inkubacji wynosiła 29,9 mm (rys. 3).

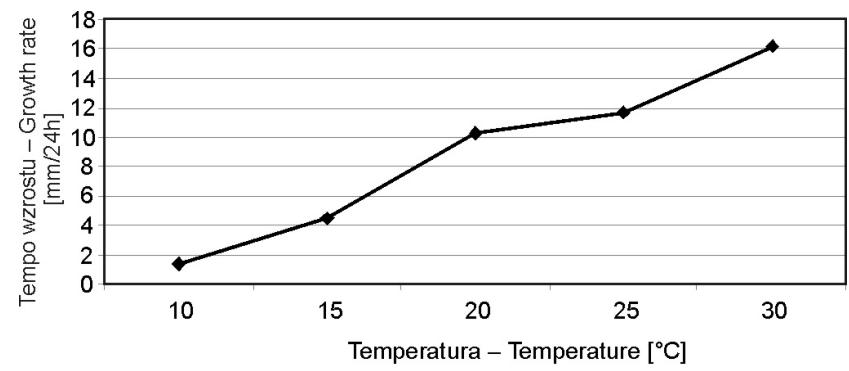

Rys. 2. Wzrost $R$. solani, izolatu pochodzącego z goździka na pożywce PDA, w zależności od temperatury

Fig. 2. Growth of $R$. solani, isolate derived from carnation on PDA medium in relation to temperature

W doświadczeniu szklarniowym stwierdzono rozwój zgnilizny podstawy pędu goździków rosnących w podłożu zakażonym izolatem $R$. solani z rośliny żywicielskiej. Po 2 tygodniach symptomy zgnilizny podstawy pędu stwierdzono na co najmniej $1 \mathrm{z} 5$ roślin $\mathrm{w}$ powtórzeniu. Po następnym tygodniu, chorobę obserwowano już na około połowie roślin. Po 28 dniach zamarło około 4/5 goździków w powtórzeniu (tab. 3 ).

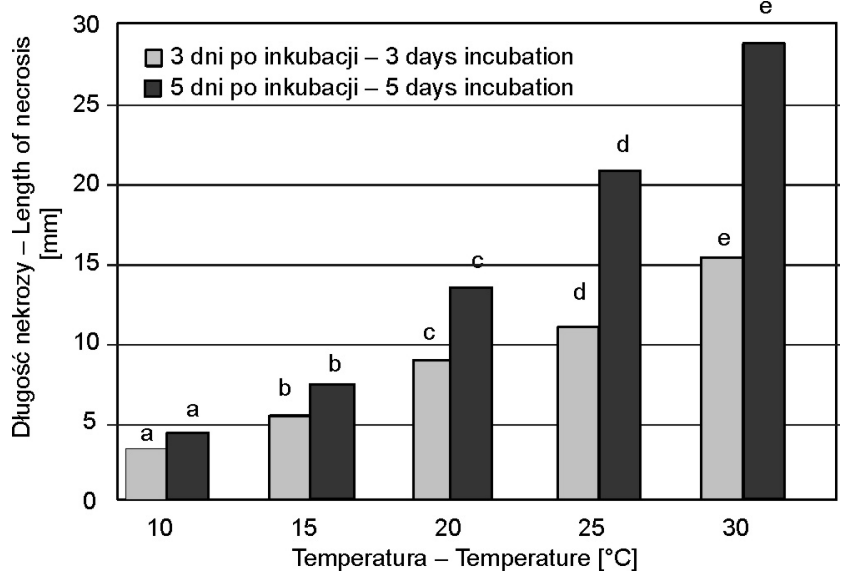

Rys. 3. Kolonizacja części łodyg goździka odmiany Genio przez izolat G1 $R$. solani w zależności od temperatury i okresu inkubacji

Fig. 3. Colonisation of stem parts of carnation cultivar Genio by isolate $\mathrm{G} 1$ of $R$. solani in relation to incubation time

Goździki uprawiane są w Polsce najczęściej w niskich i słabo wietrzonych szklarniach oraz tunelach foliowych o niewielkich możliwościach regulowania temperatury w okresie lata. Często zdarza się, że temperatura dochodzi tam do około $40^{\circ} \mathrm{C}$. Nie dziwi zatem fakt, że w gospodarstwach uprawiających goździki pojawiła się rizoktonioza uważana przez Sharma i Chandela (2013) jako choroba gorących lat. W przypadku roślin matecznych goździków, które uprawia się w temperaturze nieprzekraczającej $20^{\circ} \mathrm{C}$, jej często 2-krotny wzrost powoduje szybki rozwój patogena. Jeśli z roślin zbiera się sadzonki, grzyb wnoszony jest do mnożarki, gdzie ukorzenia się rośliny. Jest prawdopodobne, że na części takich sadzonek choroba pojawia się dopiero po ich posadzeniu na miejsce stałe i ujawnia się po kilku-kilkunastu tygodniach. Wprawdzie w badaniach własnych rizoktonioza pojawiła się na ukorzenianych roślinach $\mathrm{w}$ ciągu kilkunastu dni uprawy, ale wynikało to $\mathrm{z}$ bardzo wysokiej liczebności patogena w podłożu. Wyniki badań laboratoryjnych wskazują na zróżnicowaną reakcję odmian goździków na $R$. solani $\mathrm{i}$ było to zapewne związane ze stopniem zdrewnienia tkanek trzech badanych odmian. Zaskoczeniem jest jednak duża różnica $\mathrm{w}$ chorobotwórczości izolatów, z których E5 z eustomy kolonizował części łodyg i liście goździków około 2-krotnie wolniej aniżeli kultura G1 z goździka.

Tabela 3. Kolonizacja sadzonek goździków odmiany Genio przez $R$. solani w zależności od źródła izolatu i okresu uprawy; liczba chorych roślin $(\mathrm{n}=5)$ w doświadczeniu szklarniowych

Table 3. Colonisation of carnation cuttings cultivar Genio by $R$. solani in relations to isolate source and growing period; number of diseased plants $(n=5)$ in greenhouse trial

\begin{tabular}{l|c|c|c}
\hline \multirow{2}{*}{$\begin{array}{c}\text { Źródło izolatów } \\
\text { Source of isolates }\end{array}$} & 14 & 21 & 28 \\
\cline { 2 - 4 } & $0 \mathrm{a}$ & $0 \mathrm{a}$ & $0 \mathrm{a}$ \\
\hline Kontrola - Control & $1,3 \mathrm{~b}$ & $2,8 \mathrm{~b}$ & $4,0 \mathrm{~b}$ \\
\hline Goździk - Carnation & $0 \mathrm{a}$ & $0 \mathrm{a}$ & $0 \mathrm{a}$ \\
\hline Eustoma - Lisianthus & & & \\
\hline
\end{tabular}

Średnie w kolumnach, oznaczone tą samą literą, nie różnią się istotnie (5\%) według testu Duncana

Means in columns followed by the same letter, do not differ $(5 \%)$ according to Duncan's multiple range test 
Oznacza to, że mimo bardzo szerokiej grupy roślin żywicielskich dla $R$. solani istnieją znaczne różnice w chorobotwórczości izolatów w zależności od źródła ich pochodzenia.

Wyniki przeprowadzonych badań wskazują, że w uprawie goźdzków szklarniowych obok fuzariozy naczyniowej należy uwzględniać również rizoktoniozę $\mathrm{w}$ programie ochrony tej rośliny przed chorobami.

\section{Wnioski / Conclusions}

1. Z goździków z objawami zgnilizny podstawy pędu izolowano głównie $R$. solani.

2. W warunkach laboratoryjnych izolaty $R$. solani kolonizowały tkanki różnych odmian goździków, powodując na nich rozwój nekrozy.
3. W doświadczeniach szklarniowych po miesiącu uprawy goździków w podłożu zakażonym przez $R$. solani, zamierała większość roślin.

4. Optymalna dla rozwoju $R$. solani była temperatura $30^{\circ} \mathrm{C}$.

Opracowanie wykonano $\mathrm{w}$ ramach zadania $\mathrm{nr} \quad 1.5$ „Diagnostyka zagrożenia przez agrofagi inwazyjne, podlegające obowiązkowi zwalczania, opracowanie metod zwalczania i zapobiegania ich rozprzestrzenianiu się", Programu Wieloletniego „Rozwój zrównoważonych metod produkcji ogrodniczej w celu zapewnienia wysokiej jakości biologicznej i odżywczej produktów ogrodniczych oraz zachowania bioróżnorodności środowiska i ochrony jego zasobów", finansowanego przez Ministerstwo Rolnictwa i Rozwoju Wsi.

\section{Literatura / References}

Elad Y., Hadar Y., Hadar E., Chet I., Henis Y. 1981. Biological control of Rhizoctonia solani by Trichoderma harzianum in carnation. Plant Dis. 65: 675-677.

Hall G. 1993. An integrated approach to the analysis of variation in Phytophthora nicotianae and redescription of the species. Mycol. Res. 97: 559-574.

Mynett K. 1984. Goździki. PWRiL, Warszawa: 251-256.

Orlikowski L.B. 1999. Selective medium for the evaluation of biocontrol agents efficacy in the control of soil-borne pathogens. Bull. Pol. Acad. Sci, Biol. Sci 47 (2-4): 167-172.

Orlikowski L.B., Dzięcioł R. 1976/77. Wstępne badania nad przyczynami więdnięcia goździków szklarniowych. Prace Inst. Sadownictwa, Seria B, 2: 185-189.

Orlikowski L.B., Ptaszek M. 2013. Zagrożenie niektórych roślin doniczkowych przez Rhizoctonia solani. [Menance of some pot plants caused by Rhizoctonia solani]. Prog. Plant Prot./Post. Ochr. Roślin 53 (1): 138-141.

Orlikowski L.B., Szkuta G. 2002. Dieback of Pieris japonica caused by Phytophthora citrophthora. Acta Mycol. 36: 251-256.

Sharma S., Chandel S. 2013. Management of stem rot (Rhizoctonia solani) of carnation by fungicides. J. Mycol. Plant Pathol. 43 (2): $187-189$.

Werner M. 1997. Patogeniczność uzyskanych z gipsówki wiechowatej grzybów z rodzaju Fusarium, Phytophthora i Rhizoctonia względem goździka szklarniowego. Rocz. AR Poznań, 296, Ogrodnictwo 25: 137-143. 